Jurnal Hukum Mimbar Justitia

Fakultas Hukum Universitas Suryakancana

Vol. 3 No. 1 - Juni 2017 p. 97-116

ISSN: 2477-5681 (Cetak), ISSN: 2580-0906 (Online)

Open Access at: http://jurnal.fhukum.unsur.ac.id/ojs/

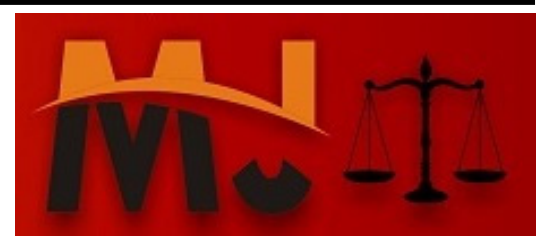

\title{
PERANAN TOKOH ADAT SEBAGAI MEDIATOR SOSIAL DALAM MENYELESAIKAN KONFLIK AGRARIA YANG MELIBATKAN MASYARAKAT ADAT MULTIKULTURAL DI INDONESIA (PERSPEKTIF KAJIAN SOCIO LEGAL RESEARCH)
}

Firman Freaddy Busroh

STIH Sumpah Pemuda Palembang

E-mail: firmanbusroh@gmail.com

\section{Masuk: Maret 2017}

Penerimaan: Maret 2017

Publikasi: Juni 2017

\begin{abstract}
ABSTRAK
Indonesia adalah bangsa yang memiliki banyak pulau di mana di dalamnya terdiri dari masyarakat tradisional yang memiliki tradisi. Setiap masyarakat tradisional memiliki pemimpin tradisional yang dihormati dan dipatuhi untuk memecahkan masalah. Tokoh adat dapat bertindak sebagai mediator sosial untuk membantu menyelesaikan masalah. Penyelesaian masalah melalui mediasi sosial mungkin lebih efektif dan efisien, terutama masyarakat multikultural di Indonesia. Dengan memberdayakan komunitas hukum adat dapat membantu pemerintah dalam menyelesaikan konflik agraria.
\end{abstract}

Kata kunci: $\quad$ Multikultural; Tokoh Adat; Mediator Sosial; Komunitas Hukum Adat; Alternatif Penyelesaian Sengketa.

\section{ABSTRACT}

Indonesia is a nation with many islands that consists of traditional society inside. That traditional community has a traditional leader who is respected and obeyed to solve the problem. Customary figures can act as social mediators in solving the problems. Problem solving through social mediation could be more effective and efficient, especially in multicultural societies like Indonesia. Empowering customary law, it can help the government in resolving agrarian conflicts.

Keywords: Multicultural; Adat leaders; Social Mediator; Community Customary Law; Alternative Dispute Resolution.

\section{PENDAHULUAN}

Di Indonesia kerapkali terjadi konflik-konflik yang beragam sifatnya seperti konflik agama, konflik investasi, konflik politik, konflik sosial, konflik hukum. Beragam konflik yang terjadi disebabkan ketidakadilan dan ketimpangan sosial dalam masyarakat. Kerapkali terjadi perbedaan yang sulit 
untuk disatukan sehingga berujung kepada kerugian yang lebih besar.

Indonesia yang memiliki rakyat yang multikultural terdiri dari beragam suku, ras, agama dan kelompok tertentu sering kali menjadi pemicu suatu kerusuhan. Beberapa peristiwa yang terjadi di Indonesia seperti konflik agama yang dipicu pernyataan inisial BTP alias A yang kemudian memunculkan reaksi meluas di seluruh Indonesia.

Di Indonesia dikenal menjunjung tinggi semboyan Bhinneka Tunggal Ika yang artinya berbeda beda tetapi tetap satu jua. Negara Indonesia memang terdiri dari beragam suku, agama, ras dan kelompok akan tetapi perbedaan tersebut tidak dapat dijadikan alasan untuk perpecahan.

Pendiri bangsa Indonesia salah satunya Presiden pertama Indonesia Soekarno telah berupaya menyatukan perbedaan antara rakyat Indonesia. Karena itulah landasan dasar negara Republik Indonesia adalah Pancasila. Kelahiran Pancasila sendiri awalnya adalah judul pidato yang disampaikan oleh Soekarno dalam Sidang dokuritsu junbi cosakai atau dalam bahasa
Indonesianya Badan Penyelidik Usaha Persiapan Kemerdekaan. ${ }^{1}$ Pancasila merupakan pemersatu bangsa Indonesia, tanpa Pancasila maka Indonesia akan terpecah belah.

$$
\text { Perjalanan sejarah bangsa }
$$

Indonesia masih kerap terjadi konflik yang disebabkan adanya perbedaan suku, agama, ras dan kelompok tertentu. Pada tahun 2016 tercatat beberapa peristiwa konflik seperti Konflik di Tanjung Balai, Asahan, Sumatera Utara pada tanggal 29 Juli 2016 disebabkan karena adanya protes tingginya volume suara Azan, Konflik Karo yang disebabkan karena rencana pembangunan tempat relokasi mandiri untuk 1.683 (Seribu enam ratus delapan puluh tiga) kepala keluarga korban erupsi Gunung Sinabung di Desa Lingga, Kec. Simpang Empat, Karo, Sumatera Utara yang mendapat penolakan masyarakat setempat. Konflik di Mimika disebabkan kasus pemukulan yang terjadi pada dua anak laki-laki asal Toraja pada tanggal 25 Juli 2016 dimana kerugian yang tercatat

1 Diunduh dari https://id.wikipedia.org/wiki/Lahirnya_Panc asila, pada tanggal 14/01/2017 pukul 11:57 WIB. 
17 (tujuh belas) rumah terbakar, 13 (tiga belas) orang luka dan 2 (dua) orang tewas.

Konflik lahan di Indonesia masih cukup tinggi dalam kurun waktu 11(sebelas) tahun terakhir dimana sejak tahun 2004 sampai dengan 2015 tercatat 1.772 (seribu tujuh ratus tujuh puluh dua) konflik agraria dengan luasan wilayah konflik seluas 6,9 (enam koma sembilan) juta hektar. ${ }^{2}$ Hal ini disebabkan banyak sekali lahan yang beralih fungsi.

Menurut hasil kajian Forest Peoples Programme (FPP) sebagaimana dikutip dari situs mongabay.co.id, ${ }^{3}$ menyebutkan bahwa nasib masyarakat adat di Indonesia yang turun temurun tinggal di sekitar kawasan hutan makin memprihatinkan. Faktor utama, karena pemerintah lemah dan tidak berpihak pada masyarakat adat. "Hutan masyarakat adat dirusak oleh

2 Diunduh dari http://www.riauonline.co.id/riau/kotapekanbaru/read/2016/01/06/konflikagraria-di-indonesia-masih-tinggiperkebunan-masih-mendominasi, tanggal 03/02/2017

3

Diunduh http://www.mongabay.co.id/2015/05/18/k onflik-masyarakat-adat-vs-perusahaanberlanjut-mengapa/, pada tanggal 03/02/2017 perusahaan seperti sawit tanpa mempertimbangkan bagaimana nasib masyarakat adat disana," kata Patrick Anderson, Policy Advisor FPP, kepada Mongabay, usai The Forests Dialogue, di Pekanbaru awal Mei 2015. Patrick Anderson mengatakan, cara sejumlah perusahaan mengeksplorasi kawasan hutan, begitu brutal tanpa mempertimbangkan masyarakat yang hidup di dalamnya. "Terjadilah konflik berkepanjangan, tidak sedikit berujung kematian”. Menurut Anderson, meskipun sudah mendapat izin pemerintah, perusahaan harus menghormati hak masyarakat adat sekitar atau kawasan hutan. "Harus dilihat ekologi, carbon, juga tapak masyarakat."Dari sejumlah laporan masyarakat adat memperlihatkan, ada sejumlah perusahaan menyatakan akan berhenti merusak hutan karena banyak tekanan pasar dan investor. Namun, komitmen itu hanya sebagian kecil, di lapangan, perusakan hutan dan konflik dengan masyarakat adat, cukup tinggi.

Konflik yang kerap terjadi tersebut perlu ada jalan penyelesaian yang cepat karena kerap kali penegakan hukum yang dilakukan kepolisian tidak mampu meredam atau menyelesaikan 
kasus bahkan beberapa kasus malah semakin menjadi karena adanya campur tangan kepolisian dalam penanganan konflik. Perlu penyelesaian yang dapat menjembatani konflik antara kedua belah pihak salah satunya dengan Mediasi.

Maraknya konflik agraria yang terjadi di Indonesia menimbulkan suatu permasalahan antara lain, bagaimana peranan tokoh adat sebagai mediator sosial dalam menyelesaikan konflik agraria yang melibatkan masyarakat adat multikultural di Indonesia?

\section{PEMBAHASAN}

Pemahaman mengenai masyarakat hukum adat bermula dari Van Vollenhoven menggambarkan bahwa hukum asli suku-suku bangsa asli di Indonesia mempunyai subjek dan objek hukum sebagaimana di Eropa. Di setiap suku, daerah memiliki istilahnya masing-masing, ada yang menyebutnya desa, kelurahan, nagari, negorji, anawoe, suku, dan sebagainya. Intinya masyarakat adat ini merupakan komunitas manusia yang menyatu sebagai satu paguyuban.
Istilah masyarakat hukum adat ini ada pula yang menyebutnya persekutuan hukum, persekutuan adatistiadat, masyarakat adat. Ada yang menolak menyebutkan sebagai masyarakat hukum adat tetapi masyarakat adat saja, sebab dalam masyarakat hukum adat tidak hanya menyangkut hukum saja, tetapi juga adat-istiadat, budaya, pertanian, bentuk rumah, kesenian, reliji, politik, dan sebagainya. Akan tetapi, persoalannya adalah bahwa yang hendak diperjuangkan untuk masuk ke dalam Konstitusi adalah persoalan hukum, dan hukum harus adat subjek dan objek hukumnya. ${ }^{4}$

Subjek hukum mempunyai hak dan kewajiban yang melekat pada masyarakat adat secara hukum disebut objek. Objek hukum norma hukum yang berisi tentang hak dan kewajiban dari subjek hukum. Harta benda adalah salah satu objek hak milik, utang piutang adalah salah satu objek hak dan kewajiban yang diatur oleh hukum. Seluruh aspek kehidupan manusia diatur oleh hukum, dilindungi oleh hukum, dan jika seseorang melanggar hukum

4 Dominikus Rato, Hukum Adat Kontemporer, LaksBang Justitia, Surabaya, 2015 , hlm. 82. 
dengan cara mengambil hak orang lain, hukum wajib memberikan perlindungan, sehingga si pelaku kejahatan oleh hukum diberi sanksi, denda, atau hukuman. ${ }^{5}$

Subjek hukum adat ialah rechtsgemeenschap atau dalam Bahasa Indonesia ada yang menerjemahkannya dengan Persekutuan Hukum Adat dan ada pula yang menyebutnya Masyarakat Hukum Adat. Kedua istilah itu pada dasarnya sama, namun perlu dilihat latar belakang mengapa Van Vollenhoven menggunakan istilah 'gemeenschap?. Ada kemungkinan istilah ini dipinjam dari konsep biolog Jerman Ferdinand Tonnies, ${ }^{6}$ yang membagi 2 (dua) kategori sosial yaitu gesselschaap (masyarakat patembayan) dan gameenschaap (masyarakat paguyuban). Dalam bukunya berjudul Gemeinschaft und Gesellschaft (tahun 1887) Tonnies memisahkan dua dasar pengertian bentuk kehidupan manusia yang berbeda:

5 Ibid,.

6 http://id.wikipedia.org/wiki/Ferdinand_Ton nies. Dikutip dalam Varon Bensoin, The Promise of the Present and the Shadow of the Past, Xlibris Corporation, 2011, hlm. 183.
1. Gemeinschaft (rasa keterikatan tradisional, misalnya masyarakat pedesaan) dengan organisasi (komunitas dengan tujuan rasional tidak seperti masyarakat di kota besar). Gemeinschaft yang ditandai dengan kepolosan, suatu yang wajar, solidaritas, keramahtamahan, hubungan tetangga yang rukun secara tradisional dan desa tradisional);

2. Gesellschaft menurut Tonnies ialah aspek tanpa bentuk kepribadian, bersifat instrumental dan memang telah diciptakan dan ditunjukkan oleh kenyataan sosial, contoh masyarakat di pasar atau perumahan yang sangat individualistis.

Van Vollenhoven dengan meminjamkan istilah gemeenschaao itu untuk menggambarkan karakter anggota masyarakat hukum adat di Indonesia ini yang penuh dengan rasa kekeluargaan (kekitaan, togetherness), musyawarah untuk mencapai mufakat, dan gotong royong, (Jw. Rumangsa melu bandarbeni $=$ merasa ikut memiliki), dan toleransi satu sama lain. Demokrasi asli Indonesia yang berfungsi menjaga kobesisocial (ikatan kekeluargaan) dan 
melestarikan komunitas itu. Oleh karena masyarakat yang demikian yang membuat, melaksanakan, menjaga, dan merevisi norma-norma hukum, maka Van Vollenhoven memberinya status sebagai subjek hukum adat dan disebut rechstgemeenschap (masyarakat hukum adat atau persekutuan hukum). Sebagai subjek hukum tentu masyarakat hukum adat memiliki hak dan kewajiban, dan berdasarkan hak kewajiban itu masyarakat hukum adat diberi tugas dan wewenang.

Nilai-nilai tersebut kemudian dijadikan suatu ideologi bangsa Indonesia yakni Pancasila. Pancasila sebagai Landasan Ideologi, UUD NRI Tahun 1945 sebagai Landasan Konstitusional, maka Negara wajib melindungi segenap bangsa Indonesia dan seluruh tumpah darah Indonesia, termasuk di dalamnya aspek sosial budaya. Hukum adat adalah salah satu aspek sosial budaya yang wajib diakui dan dilindungi oleh Konstitusi Negara Kesatuan Republik Indonesia ini.

Kewajiban lain dari Negara Kesatuan Republik Indonesia sebagaimana diatur dalam Konstitusi sebagai Hak Konstitusional warga
Negara, selain hukum adat dan hak-hak tradisionalnya ialah memajukan kesejahteraan umum. Memajukan kesejahteraan umum, salah satu instrumennya adalah hukum adat yang sudah berurat akar dalam sanubari bangsa Indonesia ini. Hukum adat adalah warisan budaya leluhur yang tidak dapat diabaikan begitu saja sekalipun Negara Kesatuan Republik Indonesia sudah berdaulat atas warga Negara, suku-suku bangsa sejak tanggal 17 Agustus 1945.

Akan tetapi, sejarah historis Negara ini tidak dibangun di atas ruang kosong. Negara ini dibangun di atas masyarakat yang secara historis dan kultural sudah ada sejak abad nenek moyang bangsa Indonesia belum mengenal tulisan, sehingga budaya yang berakar di hati masyarakat adalah budaya tutur sehingga hukum adat dibangun di atas budaya tutur itu, sehingga sebagian besar norma hukum adat ini tidak tertulis. Demikian pula, hak-hak komunal masyarakat hukum adat seperti hak-hak atas tanah tidak diatur dan ditulis di atas lembaran kertas sebagaimana di Negara-negara Eropa dimana norma-norma hukum mereka 
dibangun di atas hukum tertulis seperti kodifikasi.

Di sisi lain, di Indonesia ini terdiri dari ribuan suku bangsa sehingga hukum adat yang hidup dalam masingmasing masyarakat hukum adat itu pun ribuan, sehingga unifikasi hukum hanya mungkin bersifat formal, bukan substansial. Secara substansi/materi setiap masyarakat hukum adat itu mempunyai norma hukumnya masingmasing. Karena hukum adat yang dibangun itu lahir dari pengalaman hidup dan kebutuhan hukum yang nyata dan hidup, ketika masyarakat adat itu menghadapi masalah.

Dengan demikian, ketika rencana pembentukan Rancangan UndangUndang Pengakuan dan Perlindungan Hak Masyarakat Hukum Adat (RUU PPHMHA) dibuat, ada perbedaan pandangan tentang definisi masyarakat hukum adat. Ada yang membuat definisi, ada yang hanya membuat kriteria-kriteria, dan berbagai macam pandangan. Perbedaan ini adalah sebuah gambaran demi kebaikan dan keselamatan masyarakat hukum adat, ketika masyarakat hukum adat itu hendak diformalkan. Sebab sekali diformalkan dalam bentuk bahasa, padahal bahasa itu sangat terbatas untuk menggambarkan, menjelaskan, memahami realitas yang demikian kompleks, maka rumusan dalam bentuk keterbatasan bahasa itu dapat merugikan masyarakat hukum adat.

Mengakomodasi seluruh kategori masyarakat hukum adat dalam suatu definisi sangat sulit, sebab masyarakat hukum adat itu terbentuk berdasarkan: darah (geneologis), daerah (teritorial), territorial geneologis, geneologisteritorial.

Eksistensi hukum adat sebagai hukum positif secara legal-formal setelah amandemen UUD 1945 menjadi

\section{3} 1945 pada Pasal 18B ayat (2) UUD Negara Republik Indonesia Tahun 1945 menyatakan bahwa:

"Negara mengakui dan menghormati kesatuan-kesatuan masyarakat hukum adat beserta hak-hak tradisionalnya sepanjang masih hidup dan sesuai dengan perkembangan masyarakat dan prinsip Negara Kesatuan Republik Indonesia, yang diatur dalam undang-undang".

Selanjutnya Pasal 281 ayat (3)

UUD 1945 menyatakan:

"Identitas budaya dan hak masyarakat tradisional dihormati 
selaras dengan perkembangan zaman dan peradaban".

Jadi, hukum adat berdasarkan Pasal 281 ayat (3) merupakan identitas budaya, yang menurut Pasal 281 ayat (4) wajib direalisasikan oleh Negara. ${ }^{7}$ Berangkat dari kedua Pasal Konstitusi di atas, lahirlah beberapa Undangundang sebagai aktualisasinya seperti Undang-Undang Nomor 39 Tahun 1999 tentang Hak Asasi Manusia, UndangUndang Nomor 41 Tahun 1999 tentang Kehutanan, Undang-Undang Nomor 7 Tahun 2004 tentang Sumber Daya Air, Undang-Undang Nomor 18 Tahun 2004 tentang Perkebunan, Undang-Undang Nomor 6 Tahun 2014 tentang Desa, dan peraturan lainnya.

Saat ini hukum adat telah banyak berubah, bukan dari tidak tertulis ke hukum yang tertulis, tetapi juga kemajuan teknologi dan komunikasi serta pendidikan yang terbuka untuk anggota masyarakat, telah membentuk pola pikir masyarakat. Pola pikir ini pun terjadi dengan berbagai cara, misalnya peniruan, adaptasi, dan sebagainya. Belum lagi terjadi perkawinan antar anggota masyarakat yang semakin luas oleh issue hak asasi manusia, kebebasan, dan persamaan kedudukan dan status sosial. Oleh karena itu, hukum adat saat ini tidak seperti 15 (lima belas) atau 20 (dua puluh) tahun yang lalu, apalagi 40 (empat puluh) sampai 50 (lima puluh) tahun lalu. Hukum adat telah berkembang sangat pesat.

Dari perspektif sejarah perubahan itu disebabkan oleh 2 (dua) hal yaitu kultural dan struktural. Kultural adalah perubahan yang dikehendaki oleh para anggotanya baik karena perubahan pola pikir, kehendak untuk berubah, asismilasi, adaptasi, atau perkawinan. Perubahan struktural yang paling mencolok adalah karena peraturan perundang-undangan yang dibuat oleh pemerintah seperti UU No. 5 Tahun 1979 tentang Pemerintah Desa, kebijakan penanam modal sehingga masuknya rumah tangga uang melalui investasi besar-besarnya melalui open door policy pada zaman Orde Baru. Salah satu dampaknya adalah timbulnya konflik yang melibatkan masyarakat adat. Penyelesaian melalui jalur hukum dianggap kurang tepat karena masyarakat adat juga memiliki dan

7 Ibid,. 
menjunjung tinggi hukum adat yang berlaku di lingkungan masyarakat adat setempat, untuk itu perlu pendekatan yang persuasif dan kondusif dalam menyelesaikan konflik.

Pendekatan terhadap hukum adat dapat dilakukan secara internal hukum atau disebut pendekatan normatif, tetapi juga dilakukan secara eksternal yaitu antropologi hukum, sosiologi hukum, atau politik hukum. Akan tetapi, juga dilakukan secara interaksi antara keduanya yaitu socio-legal approach. Socio-legal Approach (pendekatan dari paradigma Sociological-jurisprudence), yaitu norma-norma hukum adat dikaji dan dipahami dengan teori-teori sosial, seperti antropologi hukum, sosiologi hukum, psikologi hukum, politik hukum, sejarah hukum. Ilmu-ilmu yang disebutkan terakhir ini merupakan ilmu bantu dari ilmu hukum. Banyak faktafakta hukum yang memerlukan bantuan teori-teori ilmu sosial.

Banyak fakta hukum yang dapat dipahami dengan menggunakan ilmu sejarah hukum, antropologi hukum, sosiologi hukum, atau gabungan ilmuilmu itu. Realitas ini demikian kompleks sehingga tidak cukup satu teori untuk menjelaskan atau memahami, sehingga dibutuhkan lebih dari satu teori untuk menjelaskan atau memahaminya. Misalnya, rebutan warisan antara 2 (dua) atau 3 (tiga) bersaudara, saling ejek, bertengkar, kemudian saling membunuh.

Pendekatan socio-legal diperlukan karena ada faktor-faktor non hukum yang mempengaruhi bekerjanya hukum. Faktor-faktor nonhukum seperti ideologi, politik, ekonomi, sosiologi, budaya, dan/atau psikologi. Gambar berikut ini dapat dijadikan gambaran bahwa seharusnya undang-undang dibuat, DPR sudah tidak lagi ikut campur dalam pelaksanaan undangundang tersebut DPR hanya mengawasi pelaksanaannya, jika terjadi penyelewengan, maka DPR memanggil Presiden sebagai Kepala Pemerintah untuk diminta pertanggungjawabannya. Menteri yang bersalah dalam penyelewengan hukum (UU) tidak boleh dipanggil oleh DPR. Menteri bertanggung jawab kepada Presiden. Akan tetapi, sering ditemukan, dengan alasan dialog, dengar pendapat, atau apapun alasannya, karena Indonesia menganut sistem Presedensiil, maka yang bertanggung jawab adalah Presiden. Menteri tidak bertanggung 
jawab kepada DPR, sehingga undangan

DPR kepada menteri itu kurang tepat. Jika hal itu terjadi, maka pendekatan socio-legal dapat menjawab persoalan yang demikian itu.

Salah satu pendekatan sociolegal adalah etnografi atau budaya. Pendekatan etnografis merupakan pendekatan pertama sekali yang digunakan oleh para ahli hukum adat, seperti Van Vollenhoven dan para muridnya. Pendekatan ini melihat hukum adat tidak hanya secara internal, tetapi juga eksternal. Hukum adat tidak membedakan apalagi memisahkan antara yang normative dan empiric. Sesuatu yang normative diwujudkan dalam bentuk perilaku yang empiric.

Jika diperhatikan sejarah hukum adat karya monumental Van Vollenhoven yang diringkas dalam karya Soekarno, terlihat jelas bahwa penemuan hukum adat adalah hasil karya para antropolog. Pendekatan etnografi yang dilakukan oleh para pemerhati hukum asli bangsa Indonesia itu menghasilkan buah pikiran yang tidak pernah lekang oleh waktu. Karyakarya monumental yang dihasilkan oleh Van Vollenhoven dan para murid serta penerusnya itu kini telah membuahkan hasil bahwa hukum adat tidak kalah bermanfaatnya dengan hukum-hukum lain di dunia.

Pendekatan etnografi digunakan karena: (1) hukum adat adalah produk budaya, sehingga pendekatan filsafat, sejarah, dan normatif. Tidak berarti pendekatan lain tidak tepat, akan tetapi keempat pendekatan di atas dinilai paling tepat; (2) hukum adat tidak dapat dipisahkan dengan masyarakat, ibarat jiwa dan raga, volkgeeist sebagaimana dikatakan oleh Von Savigny dan muridnya Puchta, das recht wirdt micht gemacht, es ist wirdt mit ddem volke (hukum itu tidak dibuat, hukum ada bersama masyarakat), artinya keberadaan hukum dan masyarakat itu seperti jiwa dan raga yang lahir bersamaan dalam satu tarikan nafas; (3) penelitian terhadap hal ini belum pernah dilakukan, sehingga pada tahap awal pendekatan etnografi diperlukan. Dalam pendekatan awal ini, etnografi, boleh digunakan penelitian dasar atau grounded research; (4) ada beberapa realitas hukum adat yang jika dikaji dengan norma hukum lain atau norma hukum Negara akan melahirkan 
perbuatan melanggar hukum. Misalnya pada masyarakat tertentu, ada perilaku "mencuri" yang diwajibkan sebagai salah satu syarat untuk melamar seorang gadis, atau pada masyarakat hukum adat tertentu perilaku "merampok" yang harus dilakukan karena perbuatan utang-piutang melahirkan rasa malu, sedangkan merampok sebagai perilaku pilihan untuk menghindari rasa malu. Contoh lain masyarakat hukum adat tertentu, perbuatan membunuh merupakan norma hukum yang wajib dilakukan untuk menutup rasa malu, padahal pada masyarakat hukum adat lainnya, perilaku pembunuh merupakan perbuatan yang sangat dilarang dan dibenci. Perilaku yang pada masyarakat hukum adat yang satu merupakan kewajiban, sedangkan pada masyarakat hukum adat lainnya merupakan perbuatan tercela yang wajib dihindari. Oleh karena itu, metode versteben-lah yang tepat untuk memahami hal itu, daripada metode normatif yang preskriptif. ${ }^{8}$

8 Dominikus Rato, Hermeneutika Hukum Adat: Memahami Istilah Keseimbangan Kosmis dalam Hukum Adat Delik. Paper Makalah Kertas Kerja Konferensi Nasional-3 Filsafat Hukum di UNAIR dengan Tema “Melampaui Perbedaan Positivisme Hukum
Ada yang mengatakan bahwa pendekatan etnografi adalah salah satu pendekatan socio-legal, sebab metode yang digunakan dipinjam dari metode penelitian antropologi dari ilmu sosial. Menurut pandangan ini bahwa pendekatan socio-legal adalah pendekatan hukum dengan meminjam metode penelitian dari ilmu sosial, yaitu antropologi. Bagi penulis, penelitian socio-legal terhadap hukum adat, khususnya penelitian hukum adat dengan pendekatan etnografi tidak meminjam metode penelitian dari ilmu sosial yaitu antropologi, melainkan sebagai epistemologi hukum adat yang

\section{7} melekat pada ilmu hukum adat itu. Secara ontology, hukum adat itu adalah hukum yang manunggal dengan masyarakat hukum adat, dengan mengacu pada pandangan dari Von Savigny, hubungan antara hukum adat dengan masyarakat hukum adat ibarat jiwa dan raga, volkfgeeist.

$$
\text { Misalnya }
$$

penelitian Atmosoedirdjo, ${ }^{9}$ yang melakukan

dan Teori Hukum Kodrat, FHI-UNAIR, Surabaya, 2013, t.hlm.

9 Atmosoedirdjo, Vergelijkende Adatrechterlijk Studie van Ostjavase Madoerezen en Osingers, Poortpers Ph.D Thesis, Rijksuinversiteiet Utrecht, Amsterdam Belanda 1952, t.hlm. 
penelitian Hukum Adat tentang

Perbedaan antara Hukum Adat Madura dan Osing. Penelitian ini tidak dilakukan secara normatif, tetapi dilakukan dengan pendekatan etnografi, sebab secara normatif, tidak ada metode yang membandingkan antara dua hukum adat yang berbeda. Dalam penelitian hukum normatif, pendekatan perbandingan hukum dilakukan terhadap minimal dua sistem hukum yang berbeda, misalnya antara sistem hukum adat dengan sistem hukum Eropa, atau antara sistem hukum adat dengan sistem hukum agama, atau antara ketiganya, sebagaimana dilakukan oleh Wirjono Prodjodikoro yang membandingkan antara hukum adat, hukum Islam, dan hukum Eropa. ${ }^{10}$ Pendekatan etnografi juga pernah digunakan oleh Keuning ${ }^{11}$ terhadap masyarakat hukum adat "Kuria" pada masyarakat Batak di Sumatera Utara.

Pendekatan yang dilakukan peneliti mencermati bahwa di dalam masyarakat adat setempat memiliki

10 Wirjono Prodjodikoro, Hukum Perkawinan di Indonesia, Cetakan keenam, Sumur, Bandung, 1974, t.hlm.

11 Keuning, Verwanschapsrecht en volksordening, huwelijksrecht en erfrecht in het Koeriagebied van Tapanoeli, Thesis, 1948. hukum adat yang berlaku di dalam lingkungannya. Hukum adat tersebut dijalankan oleh tokoh adat. Dalam penyelesaian konflik maka tokoh adat dapat berperan sebagai hakim/pemutus dan penengah/mediator. Masyarakat hukum adat lebih memilih menyelesaikan konflik dengan cara-cara musyawarah untuk mengembalikan keseimbangan yang terganggu akibat adanya perbuatan yang dianggap menyimpang oleh masyarakat adat setempat.

Salah satu jalan penyelesaian konflik dalam masyarakat hukum adat yaitu melalui Mediasi. Di dalam Collin English Dictionary and Thesaurus menyebutkan bahwa mediasi adalah kegiatan menjembatani dua pihak yang bersengketa guna menghasilkan kesepakatan $^{12}$.

Menurut J. Folberg dan A.

Taylor memaknai mediasi dengan:

"...the process by which the participants, together with the assistance of a neutral persons, systematically isolate dispute in order to develop options, consider alternative and reach consensual

\footnotetext{
12 Nurnangsih Amriani, Mediasi Alternatif Penyelesaian Sengketa Perdata di Pengadilan, PT. Raja Grafindo Persada, Jakarta, 2011, hlm. 29.
} 


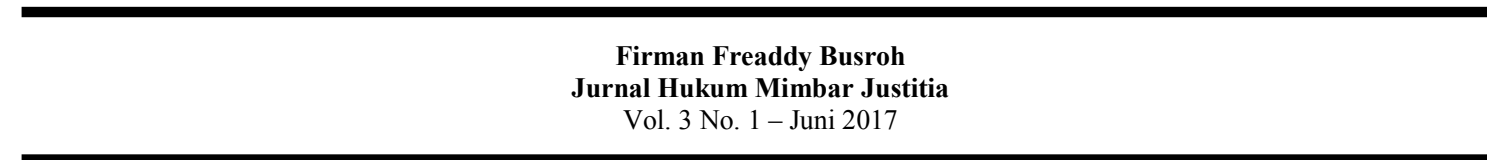

settlement that will accommodate their needs". 13

Pengertian mediasi yang dalam Kamus Besar Bahasa Indonesia mengandung 3 (tiga) unsur penting antara lain:

a. Mediasi merupakan proses penyelesaian perselisihan atau sengketa yang terjadi antar dua pihak atau lebih.

b. Pihak yang terlibat dalam penyelesaian sengketa adalah pihak-pihak yang berasal dari luar pihak yang bersengketa.

c. Pihak yang terlibat dalam penyelesaian sengketa tersebut bertindak sebagai penasehat dan tidak memiliki kewenangan apa-apa dalam pengambilan keputusan.

Berlakunya beberapa peraturan perundang-undangan di Indonesia seperti UU No. 30 Tahun 1999 tentang Alternatif Penyelesaian Sengketa dan Peraturan Mahkamah Agung Nomor 1 Tahun 2016 telah mulai menggalakkan mediasi sebagai penyelesaian yang ideal. Karena beberapa alasan:

13 Gatot Soemartono, R.M, Arbitrase dan Mediasi Di Indonesia, PT. Gramedia Pustaka Utama, Jakarta, 2006, hlm. 44. a. Biaya yang lebih murah dan waktu yang tidak lama;

b. Pendekatan yang lebih persuasif apalagi didukung ketokohan yang dihormati kedua belah pihak yang berkonflik;

c. Pembahasan permasalahan yang lebih luas, komprehensif dan fleksibel.

d. Tetap terjalinnya hubungan baik antara kedua belah pihak yang berkonflik.

Mediasi dianggap lebih efektif untuk menyelesaikan sengketa/ konflik khususnya di Indonesia. Sebetulnya konsep dan nilai mediasi sudah lama dikenal bangsa Indonesia yaitu musyawarah untuk mencapai mufakat. Nilai tersebut termasuk dalam sila keempat Pancasila. Dalam Hukum Adat di Indonesia juga mengenal beberapa penyelesaian adat seperti tappong tawar (Melayu), membasuh dusun (Lahat, Sumatera Selatan), gampong (Aceh), silih ngahampura (suku Baduy). Penyelesaian konflik melalui penerapan hukum adat dinilai lebih efektif karena masih adanya budaya malu (shame culture). Budaya malu masih dipegang teguh oleh masyarakat adat setempat. 


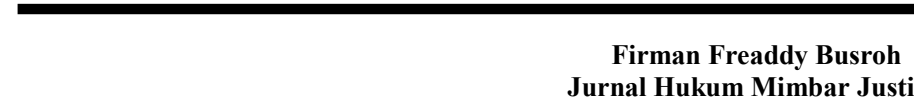

Jurnal Hukum Mimbar Justitia

Vol. 3 No. 1 - Juni 2017

\section{Masyarakat Adat dalam}

menyelesaikan konflik menyerahkan sepenuhnya kepada Tokoh Adat. Tokoh adat inilah yang berperan sebagai hakim/pemutus atau penengah/ mediator. Peran Mediator dalam menjalankan proses mediasi memperlihatkan sejumlah sikap yang mencerminkan tipe mediator. Sikap mediator dapat dianalisis dari dua sisi dimana mediator melakukan suatu tindakan semata-mata ingin membantu dan mempercepat proses penyelesaian sengketa. Pada sisi lain, tindakan mediator dalam melakukan negosiasi tidak seluruhnya dapat memuaskan para pihak yang bersengketa. Dari sikap mediator tersebut dapat diidentifikasi tipe-tipe mediator antara lain:

\section{Mediator Otoritatif.}

Tipe Otoritatif adalah mediator dimana dalam proses mediasi memiliki kewenangan yang besar dalam mengontrol dan memimpin pertemuan antar pihak. Keberlangsungan pertemuan para pihak sangat tergantung pada mediator, sehingga peran para pihak sangat terbatas dalam mencari dan merumuskan penyelesaian sengketa para pihak. Mediator dengan tipe ini dapat pula menghentikan pertemuan antar para pihak, jika merasakan pertemuan tersebut tidak efektif, tanpa meminta pertimbangan dari para pihak.

Dalam proses mediasi, mediator dengan tipe otoritatif lebih banyak mengajukan pertanyaan kepada para pihak seputar akar persoalan utama yang menjadi sumber sengketa. Mediator otoritatif tidak banyak mendengarkan cerita dari pihak yang bersengketa, tetapi lebih banyak menggali cerita dari pihak. Pada sisi ini para pihak terlihat agak pasif dalam mengemukakan persoalannya, sehingga lebih banyak bergantung pada mediator.

Mediator dengan tipe Otoritatif dapat mempercepat penyelesaian sengketa dan tidak berlarut-larut, karena mediator otoritatif terlibat cukup aktif menggali informasi dari pihak, yang pada taraf tertentu melakukan "interogasi” kepada para pihak. Mediator jenis ini aktif menawarkan solusi kepada para pihak, sehingga mereka leluasa memilih opsi tersebut. Namun, tindakan mediator yang bertipe otoritatif sangat berpeluang untuk gagalnya penyelesaian sengketa melalui jalur mediasi, karena para pihak 
terkesan tidak bebas merumuskan opsi bagi penyelesaian sengketanya.

2. Mediator Sosial Network.

Mediator dengan tipe sosial network adalah tipe mediator yang memiliki jaringan sosial yang luas untuk mendukung kegiatannya dalam menyelesaikan sengketa. Mediator ini memiliki hubungan dengan sejumlah kelompok sosial yang ada dalam masyarakat. Kelompok sosial dimaksud bertugas membantu masyarakat dalam penyelesaian sengketa, misalnya antara dua tetangganya, rekan kerjanya, teman usahanya atau antara kerabatnya. Mediator yang bertipe sosial network dalam menjalankan proses mediasi lebih menekankan bagaimana para pihak menyelesaikan sengketa melalui jaringan sosial yang ada dimilikinya guna membantu para pihak dalam menyelesaikan sengketa.

Mediator sosial network mengarahkan sengketa yang ditanganinya kepada pola-pola penyelesaian sengketa yang diperolehnya ketika bergabung dalam kelompok sosial. Keberadaan mediator jenis ini cukup penting, terutama ketika proses mediasi mengalami jalan buntu. Jaringan sosial yang dimiliki, akan memudahkannya dalam mempertahankan proses mediasi yang sedang berlangsung.

3. Mediator Independen.

Mediator independen adalah tipe mediator yang tidak terikat dengan lembaga sosial dan institusi apapun dalam menyelesaikan sengketa para pihak. Mediator jenis ini berasal dari masyarakat yang dipilih oleh para pihak untuk menyelesaikan sengketanya. Mediator independen betul-betul bebas dari pengaruh mana pun, sehingga leluasa menjalankan tugas mediasi. Mediator jenis ini sengaja diminta oleh para pihak, karena memiliki kapasitas dan skill dalam penyelesaian sengketa.

\section{1} Umumnya tipe mediator ini berasal dari tokoh masyarakat, tokoh adat atau ulama yang cukup berpengalaman dalam menyelesaikan sengketa. ${ }^{14}$

Independensi mediator tidak hanya dari sisi lembaga dan keberadaannya dalam masyarakat, tetapi juga independen dalam menjembatani, menegosiasi, dan mencari opsi bagi penyelesaian sengketa para pihak. Mediator independen menjaga imparsialitas dan netralitas dari

14 Diunduh dari http://knowledgeisfreee.blogspot.co.id/201 5/10/tipologi-mediator-dan-tahapanproses.html, pada tanggal 03/02/2017 
pengaruh mana pun termasuk dari para pihak. Mediator jenis ini semata-mata memfokuskan diri pada upaya strategis yang dapat diambil untuk mengakhiri sengketa para pihak. Mediator independen sangat bebas melakukan kreasi untuk menciptakan sejumlah opsi, tanpa tergantung pada pihak mana pun.

Mediator memegang peranan penting dalam menyelesaikan konflik. Keberhasilan mediator sangat ditentukan perilaku antara lain:

1. Problem solving atau integrasi, yaitu usaha menemukan jalan satu perkiraan mengatakan bahwa mediator akan menerapkan pendekatan ini bila para mediator memiliki perhatian yang besar terhadap aspirasi pihak-pihak yang bertikai dan menganggap bahwa jalan keluar menang-menang sangat mungkin dicapai;

2. Kompensasi atau usaha mengajak pihak-pihak yang bertikai supaya membuat konsesi atau mencapai kesepakatan dengan menjanjikan mereka imbalan atau keuntungan. Salah satu perkiraan mengatakan

bahwa mediator akan menggunakan strategi ini bila memiliki perhatian yang besar terhadap aspirasi pihakpihak yang bertikai dan menganggap bahwa jalan keluar menangmenang sulit dicapai;

3. Tekanan, yaitu tindakan memaksa pihak-pihak yang bertikai supaya membuat konsesi atau sepakat dengan memberikan hukuman atau ancaman hukuman. Salah satu perkiraan mengatakan bahwa mediator akan menggunakan strategi ini bila mereka memiliki perhatian yang sedikit terhadap aspirasi pihak-pihak yang bertikai dan menganggap bahwa kesepakatan yang menang-menang sulit dicapai;

4. Diam atau inaction, yaitu ketika mediator secara sengaja membiarkan pihak-pihak yang bertikai menangani konfliknya sendiri. Mediator diduga akan menggunakan strategi ini bila memiliki perhatian yang sedikit terhadap aspirasi pihak-pihak yang bertikai dan menganggap bahwa 


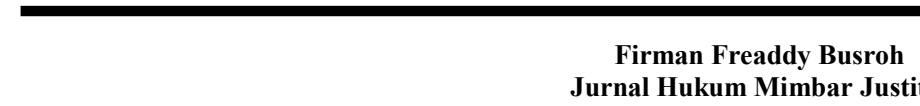

urnal Hukum Mimbar Justitia

Vol. 3 No. 1 - Juni 2017

\section{kemungkinan \\ mencapai}

kesepakatan "win-win solution". 15

Perilaku tersebut akan memiliki tingkat keberhasilan lebih tinggi bila mediator juga merupakan tokoh panutan masyarakat dimana kata-katanya dianggap diyakini memiliki kebenaran dan dipatuhi masyarakat.

Pelaksanaan mediasi sosial dalam menyelesaikan konflik dalam masyarakat, peran mediator memegang peranan penting. Mediator Sosial memiliki keunggulan karena lebih bisa menjunjung tinggi nilai-nilai kearifan lokal setempat.

Keberadaan mediator sosial ini harus dijaga kelestariannya oleh pemerintah, untuk itu pemerintah harus dapat memberdayakan melalui forum atau komunitas adat setempat, bahkan pemerintah semestinya setiap mengambil kebijakan harus memegang teguh kepada pendapat dari komunitas adat setempat. Adanya hubungan baik antara Pemerintah dengan Forum/ Komunitas Adat setempat maka konflik dalam masyarakat dapat dihindarkan.

15 Diunduh dari https://id.wikipedia.org/wiki/Mediasi\#Medi asi_di_Indonesia, pada tanggal 14/01/2017 pukul 13:16 WIB.

\section{PENUTUP}

Munculnya beberapa kasus konflik sosial karena pemerintah sering tidak bisa menampung aspirasi masyarakat. Padahal masyarakat Indonesia adalah masyarakat yang multikultural sehingga perlu pendekatan yang persuasif dalam penyelesaian sengketa.

Penyelesaian litigasi terkadang tidak mampu menyelesaikan konflik sosial dalam masyarakat, untuk itu pemerintah harus menggandeng dan memberdayakan forum/komunitas adat setempat untuk membantu pemerintah dalam menyelesaikan sengketa melalui mediasi.

Beberapa alasan mengapa mediasi menjadi alternatif penyelesaian sengketa yang ideal karena:

1. Biaya yang lebih murah dan waktu yang tidak lama;

2. Pendekatan yang lebih persuasif apalagi didukung ketokohan yang dihormati kedua belah pihak yang berkonflik;

3. Pembahasan permasalahan yang lebih luas, komprehensif dan fleksibel; 
4. Tetap terjalinnya hubungan baik antara kedua belah pihak yang berkonflik.

Peran mediator sosial dalam hal ini tokoh adat juga sangat penting dalam melaksanakan mediasi sosial. Wibawa tokoh adat sangat mempengaruhi keberhasilan mediasi, untuk itu keberadaan tokoh tersebut harus diayomi dan dijaga oleh pemerintah melalui pemberdayaan forum/komunitas adat. Komunitas adat di Indonesia harus ditumbuhkembangkan dan dilibatkan dalam penyelesaian sengketa/konflik di Indonesia. Mediasi sosial sangat dibutuhkan untuk menyelesaikan konflik dalam masyarakat multikultural di Indonesia. 


\section{DAFTAR PUSTAKA}

\section{A. Buku}

Dominikus Rato, Hukum Adat Kontemporer, LaksBang Justitia, Surabaya, 2015.

Keuning, Verwanschapsrecht en volksordening, huwelijksrecht en erfrecht in het Koeriagebied van Tapanoeli. Thesis, 1948.

Nurnangsih Amriani, Mediasi Alternatif Penyelesaian Sengketa Perdata di Pengadilan, PT. Raja Grafindo Persada, Jakarta, 2011.

RM.Gatot Soemartono, Arbitrase dan Mediasi di Indonesia, PT. Gramedia Pustaka Utama, Jakarta, 2006.

R.S.P Atmosoedirdjo, Vergelijkende Adatrechterlijk Studie van Ostjavase Madoerezen en Osingers. Amsterdam: Poortpers Ph.D Thesis Rijksuinversiteiet Utrecht, 1952.

Wirjono Prodjodikoro, Hukum Perkawinan di Indonesia, cetakan keenam. Bandung: Sumur, 1974.

\section{B. Peraturan Perundang- undangan}

Undang-Undang Dasar Negara Republik Indonesia Tahun 1945.
Undang-Undang Nomor 39 Tahun 1999 tentang Hak Asasi Manusia.

Undang-Undang Nomor 41 Tahun 1999 tentang Kehutanan.

Undang-Undang Nomor 30 Tahun 1999 tentang Alternatif Penyelesaian Sengketa

Undang-Undang Nomor 7 Tahun 2004 tentang Sumber Daya Air.

Undang-Undang Nomor 18 Tahun 2004 tentang Perkebunan.

Undang-Undang Nomor 6 Tahun 2014 tentang Desa.

Peraturan Mahkamah Agung Nomor 1 Tahun 2016

Rancangan Undang-Undang Pengakuan dan Perlindungan Hak Masyarakat Hukum Adat (RUU PPHMHA).

C. Jurnal, Makalah, Internet, dan Lain-lain.

Dominikus Rato, Hermeneutika Hukum Adat: Memahami Istilah Keseimbangan Kosmis dalam Hukum Adat Delik. Paper Makalah Kertas Kerja Konferensi Nasional-3 Filsafat Hukum di UNAIR dengan Tema "Melampaui Perbedaan Positivisme Hukum dan Teori Hukum Kodrat. Surabaya: FHIUNAIR, 2013. 
http://knowledgeisfreee.blogspot.c o.id/2015/10/tipologi-mediatordan-tahapan proses.html, pada tanggal 03/02/2017

\section{Diunduh} pada https://id.wikipedia.org/wiki/Medi asi\#Mediasi di Indonesia, pada tanggal $14 / 01 / 2017$ pukul 13:16 WIB

Diunduh pada https://id.wikipedia.org/wiki/Lahir nya_Pancasila, pada tanggal 14/01/2017 pukul 11:57 WIB

Diunduh pada http://www.riauonline.co.id/riau/k otapekanbaru/read/2016/01/06/konfli k-agraria-di-indonesia-masihtinggi-perkebunan-masihmendominasi, pada tanggal 03/02/2017 http://www.mongabay.co.id/2015/ 05/18/konflik-masyarakat-adatvs-perusahaan-berlanjutmengapa/, pada tanggal 03/02/2017

Diunduh pada http://id.wikipedia.org/wiki/Ferdi nand Tonnies. Bisa diperiksa ulang dalam Varon, Bensoin, The Promise of the Present and the Shadow of the Past. Xlibris Corporation, 2011. 